\title{
Leituras, teorias e práticas
}

https://doi.org/10.34112/2317-0972a2017v35n69pg-10

Davina Marques ${ }^{1}$

O CORPO, A VOZ, O GESTO IMPERCEPTÍVEL, A FICÇÃO. Os atos enunciativos, as implicações, os fazeres pedagógicos. As zonas de fronteiras. As propostas pedagógicas. Leituras, teorias e práticas.

Esta primeira edição de 2017 dá início ao $35^{\circ}$ ano de publicação ininterrupta da Revista Leitura: Teoria \& Prática. Para a Associação de Leitura do Brasil, isso é motivo de muito orgulho e alegria.

Nesta edição, aproveitamos para divulgar nosso projeto de publicar todos os números do periódico no formato digital. Tantos já passaram por aqui: escritores, educadores, pesquisadores, artistas... Cientes da importância histórica do debate em torno do ato de ler, da construção da resistência e da democratização da leitura no nosso país, continuamos a provocar, instigar leitor@s e pesquisador@s. Entendemos que a divulgação digital de nossos arquivos vai provocar leituras e pesquisas. Periodicamente publicaremos os números anteriores.

A primeira edição, de novembro de 1982, em seu editorial, explicitava o nosso compromisso: "servir como veículo para a comunicação e o intercâmbio entre aqueles que se preocupam com os problemas de leitura em nosso país. Destina-se, mais

1. Instituto Federal de Educação, Ciência e Tecnologia de São Paulo, Hortolândia, SP, Brasil. 
especificamente, a todos aqueles que desejam lutar pela democratização da leitura no contexto brasileiro através de um trabalho coletivo e transformador."

Reafirmamos esse compromisso nesta edição. Apresentam-se relações entre a leitura e o corpo e a voz presentes nas crônicas; promove-se uma leitura da fotografia como elemento ficcional para aproximá-la da Educação, reconhecendo o potencial emancipatório pedagógico da imagem; nos gestos imperceptíveis das escritapesquisas, problematiza-se a leitura de imagens quando não pretendem explicar, ilustrar, registrar, por exemplo, as cidades; discute-se o protagonismo da leitura em processos de formação; apresenta-se a leitura como ato enunciativo; problematiza-se a prática social da leitura como formação de leitores escolares, ao invés da formação de leitores críticos; apresentam os estágios supervisionados como possibilidades de encontros em zonas fronteiriças, como testemunhos de desfigurações das figuras já existentes - aprisionadoras do pensamento - do que seria ser um bom professor; defende-se, aliás, uma postura inventiva e responsável da posição de ensinante e nas propostas pedagógicas.

Assim, retomando as palavras de Paulo Freire, da primeira edição, seguimos formando-nos lendo.

Boas leituras! 